\title{
Kommentteja aikuiskasvatuksen tutkimusseminaarin tiimoilta
}

Tampereella elokuussa järjestetty aikuiskasvatusseminaari on varmaan monenkin messun tai oppineen disputaation arvoinen. Papillista koulutusta saamattomalle sallittaneen joidenkin vähemmän juhlallisten eikä niin kovin tieteellisten kommenttien esittäminen.

\section{Tutkimuksen hyväksikäytön ongelma}

Puheenvuorossaan Aikuiskoulutusneuvoston puheenjohtaja Tytti Isohookana-Asunmaa palautti mieliin VTL Osmo Lampisen Tiedepolitiikka-lehteen kirjoittaman artikkelin, jossa tämä toteaa, että tutkimustieto hyväksytään ja omaksutaan parhaiten silloin, kun se tukee muulla perusteella tapahtuvaa harkintaa. Tutkimustiedon heikon perillemenon eräänä syynä on pidetty sitä, ettei hallinto kykene käsittelemään tieteellistä tietoa. Itselleni on joskus tullut mieleen, onko kysymys niinkään kyvyttömyydestä kuin haluttomuudesta. Perehtyminen johonkin tutkimusraporttiin ja tulosten relevantti hyväksikäyttö hallinnollisissa ratkaisuissa voi olla varsin työlästä puuhaa. Helpompaa saattaa olla turvautuminen MUTUratkaisuihin. Mahdollista on sekin, että tutkimustiedon merkitystä edelleenkin liiallisesti vähätellään. Tällaisen suhtautumisen syntyyn eivät kaikki tutkijatkaan liene aivan syyttömiä. Kaikki nämä ja epäilemättä monet muutkin tekijät ovat vaikuttamassa siihen, ettei aikuiskasvatustutkimukselle tahdo löytyä riittävästi lisäresursseja, vaikka tutkimuksen tehostamisen merkitys yleisesti myönnetäänkin.

Hallintomiehet mainitsivat muitakin tutkimustiedon hyödyntämistä vaikeuttavia tekijöitä. Olavi Alkio totesi, että tutkimus on aina lii- an hidas voidakseen ideaalitasolla toimia hallinnon perustana. Kun puhutaan nopeita hallinnollisia ratkaisuja edellyttävistä tilanteista onkin selvää, ettei niiden perustaksi tutkimusta voida järjestää tai sitten päädytään näennäistutkimukseen. Periaatteellisten linjaratkaisujen perustana sen sijaan tutkimustieto voisi olla nykyistä enemmän. Tällöin kaivattaisiin huomattavasti lisää nimenomaan perustutkimusta. Resursseista puhuttaessa Mauri E. Virtasen kouluhallituksesta puolestaan totesi niiden lisäämisen olevan rat kaisevasti kiinni poliittisesta päätöksenteosta. Hallinnon edustaja voi yhteiskunnan rahoittamaan tutkimukseen jakaa vain ne resurssit, jotka poliittinen päätöksentekijä on tarkoitukseen osoittanut.

Joudutaankin kysymään, mikä on poliittisen päätöksentekijän suhde tutkimukseen ja tutkimustiedon käyttämiseen päätöksiä tehtäessä. Onko sillä taholla kykyä ja halua käsitellä tieteellistä tietoa? Tieteellisen koulutuksen puuttuminen voi tehtä maallikolle vaikeaksi tutkimustiedon ymmärtämisen ja sen asettamisen oikeisiin yhteyksiinsä. Tässäkin tutkijat voivat olla osasyyllisiä, kun heidän käyttämänsä ilmaukset ovat asiantuntijaslangia tai suorastaan "postmodernia diskursiota", Aulis Alasta lainatakseni. (Olisikohan tutkimusraporttien laatijoille ja muille tutkimuksesta tiedottaville järjestettävä kielenkäytön ymmärrettävyyden lisäämiseen tarkoitettua koulutusta, kuten mm. opetushallinnon edustajille jo on järjestetty?) Myös tutkimustulosten ristiriitaisuus ja todennäköisyysluonne voivat aiheuttaa vieraantumisoireita poliittisissa päättäjissä. Poliitikoilla saattaa olla myös liiallisia odotuksia tutkimukseen nähden, tutkijan tulisi temmata yksiselitteinen ratkaisu monimutkaisiin ongelmiin vähän samaan tapaan kuin taikuri vetää hatustaan kaniinin tai jonkin muun eläväisen. 
Aikuiskoulutus/kasvatus kuten kaikki muukin yhteiskunnallinen toiminta on arvosidonnaista. Merkittävä osa alan tutkimustulosten ristiriitaisuuksista johtunee siitä, että tämä arvosidonnaisuus on heikosti tiedostettu eikä tutkija ole riittävästi analysoinut omia arvoperusteitaan. Poliittinen päättäjä, mikäli hän ylipäätään turvautuu harkinnoissaan tutkimustietoon, tukeutuu lähinnä niihin tuloksiin, jotka vastaavat hänen näkemyksiään ja joihin on päädytty hänen omaksumistaan arvolähtökohdista käsin. Tutkimuksen käyttöarvoa ei tällöin enää määrääkään esimerkiksi sen tieteellinen taso vaan lähtökohtana olleet joko selvästi ilmaistut tai ilmaisemattomat arvostukset.

\section{Arvokysymykset puntariin}

Arvokysymykset olivat tässä seminaarissakin vahvasti esillä. Tosin ei varsinaisesti pohdittu aikuiskoulutuksen arvomaailmaa, mutta monessa puheenvuorossa se oli mukana tietynlaisena itsestäänselvyytenä. Varsin selvästi tämä kävi ilmi esimerkiksi Kari Purhosen alustuksessa, kun hän tarkasteli teollisuuden aikuiskoulutuksen tutkimukseen kohdistamia odotuksia. Teollisuuden ja yleensäkin tuotantoelämän lähtökohdista käsin ja näiden lähtökohtien kannalta aikuiskoulut usta ja sen tutkimusta tarkasteltiin johdonmukaisesti ja selkeästi. Mutta on kysyttävä, missä määrin nämä lähtökohdat ja niistä käsin toteutettava koulutus ovat sopusoinnussa muiden ja ehkä yleisluontoisempien koulutus- ja yhteiskuntapoliittisten periaatteiden kanssa. Esimerkiksi teollisuuden asettamista aikuiskoulutuksen viidestä tavoitteesta jokaisessa tulee voimakkaasti esiin ajatus, jonka mukaan aikuiskoulutuksen päätarkoituksena on tuottaa teollisuuden (tuotantoelämän) käyttöön mahdollisimman tehokkaita ja käyttökelpoisia työntekijöitä. Vain yhdessä tavoitelausumassa on sanonta, jonka hyvällä tahdolla voi ymmärtää viittaavan yksilön kaikinpuolisen kehittämisen periaatteeseen. Vaikka hyväksyisikin näkemyksen (sinänsä kyseenalaisen), että tuotantoelämän hyvinvointi takaa myös yksityisten kansalaisten hyvinvoinnin, joutuu kuitenkin kysymään, eikö teollisuudenkin lähtökohdista lähtien olisi aiheellista nähdä ihminen hieman muunakin kuin tuotantoelämän välikappaleena.

Aika mielenkiintoisia ajatusyhtymiä syntyy, kun tarkastellaan toteamusta: Ammatillisen aikuiskoulutuksen tarjonnan tulee perustua todettuun koulutustarpeeseen. Kuka toteaa? Teollisuuden ja tuotantoelämän edustajat, tut- kijat, hallinto vai ehkä potentiaaliset koulutettavat itse? Vaikka eri tahojen suorittamat tarvearvioinnit voivat kin joissakin tapauksissa olla yhteneväiset, kannattanee kysymystä melko tarkkaan pohtia. Jos taas lähdetään siitä, että "'koulutustarvetta on, kun henkilöiltä puuttuu niitä tietoja, taitoja tai asenne, joita nykyisen tai tulevan tehtävän menestyksellinen suorittaminen edellyttää ja puuttuvia valmiuksia voidaan lisätä koulutuksella', ja yhdistetään tämä esimerkiksi Jukka Tuomiston esittämään tietoon työnantajien järjestämään koulutukseen osallistumisesta, voidaan päätyä yllättäviin kysymyksiin. 'Kuten tunnettua, ovat työntekijät osallistuneet työnantajien koulutukseen huomattavasti vähemmän kuin toimihenkilöt. Lisäksi on havaittu, että työnantajat arvioivat näiden ryhmien koulutustarpeen samansuuntaisesti, eli työntekijöiden arvioidaan tarvitsevan vuosittain vain noin yhden koulutuspäivän, kun taas ylimmän johdon katsotaan tarvitsevan koulutusta 5-6 päivää vuodessa', näin Tuomisto. Puuttuuko nyt ylimmältä johdolta suhteellisesti ottaen enemmän tehtävän suorittamisessa tarpeellisia tietoja, taitoja ja asenteita kuin työntekijöiltä? Vai ovatko työntekijät oppimiskyvyltään ylivertaisia ylimpään johtoon nähden? Ilmeistä on, ettei yllä mainittu koulutuksen osallistumisen jakauma osoita aikuiskoulutuksen ainakaan näissä tapauksissa toimivan koulutuseroja vähentävästi, mikä kuitenkin on nähty varsin keskeiseksi aikuiskoulutuspolitiikan yleisperiaatteeksi.

Monet Kari Purhosen esittämistä koulutuksen toteuttamiskeinoista ovat varmaan yleispäteviä. Esimerkiksi kannustaminen itsensä kehittämiseen, valmiin kapasiteetin käyttöasteen nostaminen, didaktinen tehostaminen, koulutustilaisuuksista tiedottaminen entistä paremmin jne. ovat kaikessa koulutuksessa huomionarvoisia näkökohtia. Samaa voi sanoa monista esitetyistä tutkimusaiheista. Mutta jos yrittäjyys nähdään vain taloudellisena eikä ylcisempänä yritteliäisyytenä, joudutaan kysymään, missä määrin tutkimuspanosta tähän aiheeseen tulee sijoittaa. Kyseenalainen voisi olla myös kustannus - hyöty - tut kimus lähtien näkemyksestä, jonka mukaan koulutusta tulisi tarkastella kustannus-hyöty -periaatteen mukaisesti. Mikä hyöty? Miten hyöty mitataan? Vainko taloudellinen tai tuotannollinen hyöty?

Ammatillista aikuiskoulutusta ja ns. yleissivistävää tai ihmisen kokonaispersoonallisuuden kehittämiseen tähtäävää aikuiskoulutusta ei tule nähdä toistensa vastakohtina. Molempia tarvitaan ja ne oikein toteutettuina täyden- 
tävät toisiaan. Laaja yleissivistys on ihmistä ammatissaan ja näin myös tuotantoa palveleva tekijä. Toisaalta myös ammatti ja ammattisivistys kehittävät ihmisen kokonaispersoonallisuutta, vieläpä varsin voimakkaasti. Mutta jos ammatillista koulutusta, myös ammatillista aikuiskoulutusta, toteutetaan ja kehitetään silmällä pitäen yksipuolisesti ja voimakkaasti materiaalista hyötyä ja koulutuksesta tuotannolle koituvaa panos-tuotos-suhteen paranemista, ollaan vaarallisella polulla. Tällainen korostus saattaa vahvistaa utilitaristista asennetta kohtuuttomasti, niin että kaikkia asioita ja toimintoja arvioidaan pelkästään niistä koituvan hyödyn mukaan. Reaktiona saattaa toisaalta syntyä kaikennäköisiä vihreitä liikkeitä, jopa mustanpunaisia, kuten viime vuosikymmenen tapahtumat osoittavat.

\section{Vapaan sivistystyön perusteiden tutkimus}

Juha Sihvonen Valkeakoskelta tarkasteli aikuiskoulutuksen tutkimustarpeita vapaan sivistystyön kannalta. Hän piti vapaan sivistystyön perusteiden jatkuvaa tutkimusta ensiarvoisen tärkeänä. (Sama koskee varmaan koko aikuiskoulutusta.) Sihvosen mukaan vapaan sivistystyön itseymmärryksen kehittämisen perinne on katkennut. Tämä on ilmeisesti ymmärrettävä niin, että kaivataan filosofisen perustutkimuksen tehostamista ja aikuiskoulutuksen kehittämistä näin saatujen tulosten pohjalta. Filosofisen näkökulman tärkeyttä aikuiskoulutuksen tutkimuksessa korosti myös Ritva Jakku-Sihvonen. Nimenomaan didaktinen tutkimus kaipaisi filosofiselta pohjalta lähtevää monitieteistä lähestymisotetta. Näistä lähtökohdista voitaisiin ja tulisikin kyseenalaistaa monia koulutuskäytännössä ja koulutustutkimuksessakin vakiintuneita näkemyksiä.

Toinen Juha Sihvosen ja eräiden muidenkin esittämä ajatus sisälsi sen, että aikuiskoulutuksessa tulisi saada yleistymään ns. tut kiva työn kehittämisen periaate. Tällöin jokainen työntekijä olisi omaa toimintaansa koskevan tutkimuksen subjekti. Tämä tekisi toiminnasta vireää ja uudistuvaa, eivätkä työntekijät ehkä nujertuisi viimeistään kymmenen vuoden toiminnan jälkeen eivätkä sortuisi "'eskapisteiseen kulutusorientaatioon" yhtä helposti kuin nykyisin valitettavan usein tapahtuu. Tällaisten kokonaisnäkemyksen tarpeellisuutta korostavien puheenvuorojen yhteydessä tahtoo vain nousta mieleen hieman surumielinen muistuma mo- nista aikuiskouluttajien koulutukseen liittyvistä tilanteista, jolloin koulutettavat eivät juurikaan halua kuulla kokonaisnäkemyksistä, vaan vaativat jonkinlaista temppu- tai niksilogiaa, jonka turvin selviytyä jokapäiväisistä tehtävistään. Varsinkin aloittelevien kouluttajien/opettajien osalta tämänkin ymmärtää.

\section{Prosentti tutkimukseen?}

Ainoana puheenvuoron käyttäjistä Olavi Alkio otti esiin kysymyksen aikuiskoulutusta harjoittavien laitosten ja järjestöjen tutkimusvastuusta. Kyse tuskin oli hallinnon halusta vähentää omaa vastuutaan. Jos aikuiskoulutusinstituutiot katsovat tutkimustiedon hyödylliseksi oman toimintansa kehittämisessä ja tutkimuksen näin muodoin tarpeelliseksi, on vähintäänkin aiheellista kysyä, miksi ne eivät toimi aktiivisemmin tutkimuksen hyväksi. Käytännön vaikeuksia toki on, esimerkiksi työntekijöiden toimenkuvat, joissa ei tutkimusta tunneta työnä eivät kä mahdolliset henkilöresurssit näin ole irrotettavissa tutkimustyöhön, olletikin, kun tiedetään valtion ja kuntien byrokratian jäykkyys mm. toimien/virkojen perustamisessa ja niiden toimenkuvien muuttamisessa. Mutta varojen irrottaminen saattaisi olla helpommin toteutettavissa. Urpo Harva esitti jo 1960-luvulla ajatuksen siitä, että vapaalle sivistystyölle valtion tulo- ja menoarviossa osoitetusta määrärahasta varattaisiin $1 \%$ vuosittain tutkimukseen. Jokainen voi nykypäivänä helposti laskea, että kysymys ei olisi aivan mitättömästä summasta. Vaikka määrärahojen yleinen niukkuus myönnetäänkin, olisi tuskin ylivoimaista menetellä Harvan esittämällä tavalla.

\section{Kehityshakuisuus ja vuorovaikutus tärkeää}

Seminaarissa toistettiin useissa puheenvuoroissa kahta merkittävää periaatetta. Pidettiin tärkeänä, että harjoitettava tutkimus olisi tulevaisuuteen suuntautuvaa, kehityshakuista. Toisaalta korostettiin tutkimuksen ja aikuiskoulutuksen kentän eri edustajien jatkuvan vuorovaikutuksen tarpeellisuutta. Näiden periaatteiden toivoisi toteutuvan tutkimuskäytännössä. Kaiken kaikkiaan nyt pidetty seminaari oli onnistuneimpia pitkiin aikoihin. Kuullut alustukset ja puheenvuorot jättivät varmaan mietittävää harvinaisen monilta aikuiskoulutuksen sektoreilta tulleille osallistujille. 